\title{
Blood Stem Cell Collections after Mobilization with Combination Chemotherapy Containing Ifosfamide Followed by G-CSF in Multiple Myeloma
}

\author{
C. Straka ${ }^{a} \quad$ H. Hebart ${ }^{b} \quad$ S. Adler-Reichel ${ }^{a} \quad$ N. Werding ${ }^{a} \quad$ B. Emmerich ${ }^{a}$ \\ H. Einsele ${ }^{b}$ \\ a Medizinische Klinik-Innenstadt, Klinikum der Universität München, München und b Medizinische Klinik, \\ Klinikum der Universität Tübingen, Tübingen, Deutschland
}

\section{Key Words}

Peripheral blood stem cells · Mobilization - Stem cell collection · Multiple myeloma · G-CSF · Ifosfamide

\begin{abstract}
High-dose chemotherapy with autologous peripheral blood stem cell transplantation is the standard treatment of patients with multiple myeloma today. In this study we used a combination mobilizing chemotherapy containing ifosfamide with G-CSF before stem cell collection. The chemotherapy regimen consisted of ifosfamide $\left(2,500 \mathrm{mg} / \mathrm{m}^{2}\right.$ days $\left.1-3\right)$, epirubicin $\left(100 \mathrm{mg} / \mathrm{m}^{2}\right.$ day 1$)$ and etoposide ( $150 \mathrm{mg} / \mathrm{m}^{2}$ days $1-3$ ) followed by G-CSF ( $5 \mu \mathrm{g} / \mathrm{kg}$ from day 5 ). In 30 younger patients (median age 51 years; range $41-60$ years) who received the IEV regimen in $100 \%$ dosage, a median of $11.15 \times 10^{6} \mathrm{CD}^{4} 4^{+}$

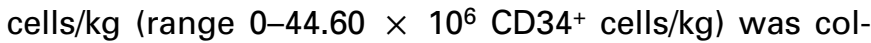
lected. In 22 elder patients (median age 64 years; range 59-72 years) similar collection results were obtained with a median of $10.82 \times 10^{6} \mathrm{CD}^{2} 4^{+}$cells $/ \mathrm{kg}$ (range 0.99 $42.22 \times 10^{6} \mathrm{CD}^{2} 4^{+}$cells $/ \mathrm{kg}$ ) after the IEV regimen in $75 \%$ dosage. The pretreatment chemotherapy cycles before mobilization were fewer in elder patients with a median of 0 cycles (range $0-7$ cycles) compared with younger
\end{abstract}

patients with a median of 4 cycles (range 0-7 cycles). These collection results were favorable and allowed to support a tandem transplantation procedure in younger and elder patients in 97 and 95\%, respectively. In the majority of patients, the hematological toxicity of IEV was of WHO grade $3 / 4$. The extramedullary toxicity was mild to moderate and there were only few cases (5-10\%) of relevant nephrotoxicity or neurotoxicity associated with the application of ifosfamide.

Copyright $(2003$ S. Karger AG, Basel

\section{Introduction}

High-dose therapy followed by autologous peripheral blood stem cell transplantation was found to be superior to conventional chemotherapy in patients with multiple myeloma [1-4]. Gianni et al. [5, 6] pioneered the use of chemotherapy with hematopoietic growth factors to mobilize and collect peripheral blood stem cells in lymphoma and multiple myeloma. The standard mobilization regimen in multiple myeloma in the 1990s was high-dose cyclophosphamide $\left(4-7 \mathrm{~g} / \mathrm{m}^{2}\right)$ followed by GM-CSF or GCSF [7-9]. Clinical studies which aim at improving the yield of stem cell collections with combination chemo-

\begin{tabular}{ll}
\hline KARGER & ( ) 2003 S. Karger AG, Basel \\
Fax + 416130-2414/03/0656-0094\$19.50/0 \\
$\begin{array}{l}\text { E-Mail karger@karger.ch } \\
\text { www.karger.com }\end{array}$ & $\begin{array}{l}\text { Accessible online at: } \\
\text { www.karger.com/ocl }\end{array}$
\end{tabular}

Dr. Christian Straka, Stammzelltransplantation

Medizinische Klinik-Innenstadt, Klinikum der Universität München

Ziemssenstrasse 1, DE-80336 München (Germany)

Tel. +49 8951602278 , Fax +49 8951604424

E-Mailcstraka@medinn.med.uni-muenchen.de 
therapy as compared to single-agent cyclophosphamide are ongoing. To optimize stem cell collections is important because nowadays frequently tandem transplantation programs [2] are offered to patients with multiple myeloma which were found to improve survival over single high-dose chemotherapy in a prospective randomized trial [10].

The median age at diagnosis in patients with multiple myeloma is between 65 and 70 years. Today, high-dose chemotherapy with melphalan and autologous blood stem cell transplantation is increasingly being offered to elder patients. Age-adapted dosing of melphalan in high-dose protocols appears to be favorable [11,12]. The outcome of elder patients with multiple myeloma treated with highdose chemotherapy does not seem to be inferior to the results obtained for younger patients $[11,13,14]$.

In this investigation we used a combination of ifosfamide $\left(2,500 \mathrm{mg} / \mathrm{m}^{2}\right.$ days $\left.1-3\right)$, epirubicin $\left(100 \mathrm{mg} / \mathrm{m}^{2}\right.$ day 1$)$ and etoposide $\left(150 \mathrm{mg} / \mathrm{m}^{2}\right.$ days $\left.1-3\right)$ followed by G-CSF $(5 \mu \mathrm{g} / \mathrm{kg})$ for stem cell mobilization and collection in multiple myeloma. There is experience with this combination for stem cell mobilization in lymphoma patients [15]. The combination of ifosfamide, epirubicin and etoposide with G-CSF was found to produce better collection results than high-dose cyclophosphamide alone with G-CSF. Here we report our experience with this mobilization regimen in multiple myeloma. For patients above the age of 60 , generally a dose reduction to $75 \%$ was carried out.

\section{Patients and Methods}

\section{Patients}

Two cohorts of consecutive multiple myeloma patients were treated in age-adapted high-dose chemotherapy protocols of the German Study Group on multiple myeloma (DSMM) at two centers. The characteristics of the patients are shown in table 1.

\section{IEV Chemotherapy and G-CSF}

The IEV chemotherapy regimen was given for blood stem cell mobilization. The IEV regimen consists of ifosfamide $2,500 \mathrm{mg} / \mathrm{m}^{2}$, i.v., days $1-3$, epirubicin $100 \mathrm{mg} / \mathrm{m}^{2}$, i.v., day 1 , and etoposide $100 \mathrm{mg} / \mathrm{m}^{2}$, i.v., days $1-3$, followed by G-CSF (filgrastim; Amgen, Thousand Oaks, Calif., USA) at a dose of $5 \mu \mathrm{g} / \mathrm{kg}$, s.c., daily from day 5 until the completion of blood stem cell harvesting. The younger patients up to an age of 60 years received the IEV regimen in a 100\% dosage. Apart from individual dose reductions, patients with an age of 60 years or above generally received the IEV regimen in a $75 \%$ dosage.

\section{Blood Stem Cell Collection and Cryopreservation}

Autologous blood stem cells were harvested when the post-nadir, G-CSF-stimulated leukocyte count rose up to 5,000-10,000/ $\mu$ or above using a Cobe Spectra (Cobe, Heimstetten, Germany) or an
Table 1. Patient characteristics

\begin{tabular}{|c|c|c|}
\hline & Younger patients & Elder patients \\
\hline Number & 30 & 22 \\
\hline \multicolumn{3}{|l|}{ Age } \\
\hline Median & 51 & 64 \\
\hline Range & $41-60$ & $59-72$ \\
\hline \multicolumn{3}{|l|}{ Gender } \\
\hline Male & $17(57 \%)$ & $11(50 \%)$ \\
\hline Female & $13(43 \%)$ & $11(50 \%)$ \\
\hline \multicolumn{3}{|l|}{ Salmon-Durie stage } \\
\hline I & $1(3 \%)$ & - \\
\hline II & $12(40 \%)$ & $5(23 \%)$ \\
\hline III & $17(57 \%)$ & $17(77 \%)$ \\
\hline \multicolumn{3}{|l|}{ M-protein type } \\
\hline G & $20(67 \%)$ & $15(68 \%)$ \\
\hline A & $2(7 \%)$ & $2(9 \%)$ \\
\hline $\mathrm{M}$ & $1(3 \%)$ & - \\
\hline Bence-Jones & $5(17 \%)$ & $5(23 \%)$ \\
\hline Anaplastic & $1(3 \%)$ & - \\
\hline Non-secretory & $1(3 \%)$ & - \\
\hline \multicolumn{3}{|l|}{ Creatinine } \\
\hline$>2 \mathrm{mg} \%$ & $2(7 \%)$ & $2(9 \%)$ \\
\hline$<2 \mathrm{mg} \%$ & $28(93 \%)$ & $20(91 \%)$ \\
\hline \multicolumn{3}{|c|}{$\beta_{2}$-Microglobulin, mg/l } \\
\hline Median & 3.3 & 3.4 \\
\hline Range & $1.0-11.5$ & $1.9-9.2$ \\
\hline \multicolumn{3}{|l|}{$\mathrm{CRP}, \mathrm{mg} / \mathrm{dl}$} \\
\hline Median & 0.4 & 0.5 \\
\hline Range & $0.1-11.0$ & $0.1-4.6$ \\
\hline
\end{tabular}

AS104 (Fresenius, St. Wendel, Germany) cell separator and standard programs. Approximately 101 of blood were processed at a flow rate of $50 \mathrm{ml} / \mathrm{min}$. The harvested blood stem cells were mixed with an equal volume of a freezing solution which was prepared with $5 \%$ HSA and 100\% DMSO (Cryoserv, Tera Pharmaceuticals, Midvale, Utah, USA) (4:1). The final DMSO concentration was $10 \%$. After computerized controlled-rate freezing, the bags containing the blood stem cells were stored in the vapor phase of liquid nitrogen.

\section{CD34 ${ }^{+}$Cell Enumeration of Autologous Blood Stem Cells}

The determination of $\mathrm{CD} 34^{+}$cells was carried out according to the guidelines of ISHAGE [16] using a FACScan (BD, Mountain View, Calif., USA) or an EPICS XL-MCL (Electronics, Miami, Fla., USA) flow cytometer equipped with an argon laser. Whole blood was incubated for $30 \mathrm{~min}$ at $4^{\circ} \mathrm{C}$ in the dark with the PE-conjugated monoclonal anti-CD34 antibody and the FITC-conjugated monoclonal anti-CD45 antibody followed by a wash and red blood cell lysis (BD). Seventy-five thousand cells were analyzed. To exclude cell debris, platelets, remaining red cells and all CD45-negative cells, a forward scatter versus CD45 fluorescence dot plot was used. The double-positive $\mathrm{CD} 34^{+} / \mathrm{CD} 45^{+}$cell population was then defined and backgated for low CD45 expression and low side scatter properties. The percentage of the so defined $\mathrm{CD} 34^{+}$cells was multiplied with the total nucleated cell content of the apheresis product to obtain the absolute number of $\mathrm{CD} 34^{+}$cells harvested. The nucleated cell con- 
Table 2. Treatment characteristics and collection results

\begin{tabular}{|c|c|c|}
\hline & Younger patients & Elder patients \\
\hline Number & 30 & 22 \\
\hline \multicolumn{3}{|c|}{ Chemotherapy cycles } \\
\hline Median & 4 & 0 \\
\hline Range & $0-7$ & $0-7$ \\
\hline \multicolumn{3}{|c|}{ Radiation therapy } \\
\hline Yes & $13(43 \%)$ & $6(28 \%)$ \\
\hline No & $17(57 \%)$ & $16(72 \%)$ \\
\hline \multicolumn{3}{|l|}{ IEV dose } \\
\hline $50 \%$ & - & $1(5 \%)$ \\
\hline $66 \%$ & $1(3 \%)$ & - \\
\hline $75 \%$ & $2(7 \%)$ & $21(95 \%)$ \\
\hline $100 \%$ & $27(90 \%)$ & - \\
\hline \multicolumn{3}{|l|}{ Leukaphereses } \\
\hline Median & 2 & 2 \\
\hline Range & $0-5$ & $1-6$ \\
\hline \multicolumn{3}{|c|}{$\mathrm{CD} 4^{+}$cells collected, $\times 10^{6} / \mathrm{kg}$} \\
\hline Median & 11.15 & 10.82 \\
\hline Range & $0-44.60$ & $0.99-42.22$ \\
\hline \multicolumn{3}{|c|}{ Proportion with $>4 \times 10^{6} / \mathrm{kg}$} \\
\hline CD34+ cells & $97 \%$ & $95 \%$ \\
\hline
\end{tabular}

tent was determined by automated cell counting using a Coulter STKS (Coulter, Miami, Fla., USA). The anti-CD34 antibody (HPCA-2), the anti-CD45 antibody (2D1) and the isotype controls used were from BD.

\section{High-Dose Treatment Protocols}

The IEV regimen was part of a sequential treatment plan. Up to an age of 60 years, patients first received induction chemotherapy with 3-4 cycles of ID or VAD. Then the IEV regimen was applied. After adequate stem cell collections, the patients proceeded either to tandem high-dose melphalan at a dose of $200 \mathrm{mg} / \mathrm{m}^{2}$ or to a single high-dose treatment with an intensified conditioning regimen consisting of total marrow irradiation with shielding of the liver and the lungs $(3 \times 2 \times 1.5 \mathrm{~Gy})$, busulfan $9 \mathrm{mg} / \mathrm{kg}$, and cyclophosphamide $2 \times 60 \mathrm{mg} / \mathrm{kg}$. At an age of 60 years and above, the patients were either treated with dexamethasone alone or with 3-4 cycles of ID or VAD before IEV. When stem cell collections were adequate, the patients proceeded to tandem high-dose melphalan at a dose of 100 $140 \mathrm{mg} / \mathrm{m}^{2}$.

\section{Results}

Younger (median age 51 years; range $41-60$ years) and elder (median age 64 years; range 59-72 years) multiple myeloma patients were treated with a combination of ifosfamide, epirubicin and etoposide (IEV) followed by G-CSF before blood stem cell collections. The patient characteristics for both cohorts of patients are shown in
Table 3. Toxicity of IEV chemotherapy

\begin{tabular}{lcc}
\hline & Younger patients & Elder patients \\
\hline $\begin{array}{l}\text { Number } \\
\text { Hematological }\end{array}$ & 30 & 22 \\
WHO grade 1 & $1(3 \%)$ & $1(5 \%)$ \\
WHO grade 2 & $7(23 \%)$ & $1(5 \%)$ \\
WHO grade 3 & $5(17 \%)$ & $7(31 \%)$ \\
WHO grade 4 & $17(57 \%)$ & $11(50 \%)$ \\
Undetermined & - & $2(9 \%)$ \\
Infection & $3(10 \%)$ & $2(9 \%)$ \\
WHO grade 1/2 & 0 & $1(5 \%)$ \\
WHO grade 3 & & $4(18 \%)$ \\
Gastrointestinal & $3(10 \%)$ & $2(9 \%)$ \\
WHO grade 3/4 & & 0 \\
Neurological & $1(3 \%)$ & $1(5 \%)$ \\
WHO grade 1/2 & $1(3 \%)$ & $1(5 \%)$ \\
WHO grade 3/4 & $1(3 \%)$ & \\
Nephrological & $1(3 \%)$ & \\
WHO grade 1/2 & & \\
WHO grade 3/4 & &
\end{tabular}

table 1. All patients were in stage II or III of their disease with the exception of 1 stage I patient. Less than $10 \%$ in both cohorts had a creatinine level $>2 \mathrm{mg} \%$. The levels of $\beta_{2}$-microglobulin and C-reactive protein were also similar in both groups. Pretreatment with chemotherapy, however, had been carried out with more cycles in the younger patient group (table 2). Dexamethasone alone was the treatment before stem cell mobilization in $45 \%$ of elder patients but only in 3\% of younger patients. Pretreatment with radiotherapy again was similar for both groups.

The younger patients usually were to receive a $100 \%$ dosage of the IEV regimen, what was actually carried out in $90 \%$ of younger patients. In 2 patients, the dose was reduced to $75 \%$ because of renal insufficiency and in 1 patient IEV could not be completed because of neurological toxicity of ifosfamide, resulting in a reduced dose of ifosfamide and etoposide of $66 \%$. The elder patients usually were to receive a $75 \%$ dosage of IEV, what was possible in $95 \%$ of patients. In 1 patient the dose was further reduced to $50 \%$ because of renal insufficiency.

The number of leukapheresis harvests carried out in both patient groups was similar with a median of two leukaphereses (table 2). Also the number of $\mathrm{CD}_{3} 4^{+}$cells collected was similar between younger patients with a median of $11.15 \times 10^{6} \mathrm{CD} 34^{+}$cells $/ \mathrm{kg}$ and the elder patient cohort with a median of $10.82 \times 10^{6} \mathrm{CD} 34^{+}$cells/ 
$\mathrm{kg}$. In 1 younger patient, stem cell collection was not possible because of chemorefractory disease and persistence of hyperviscosity after IEV. Since the patients were candidates for a tandem high-dose chemotherapy with melphalan, $4 \times 10^{6} \mathrm{CD} 34^{+}$cells $/ \mathrm{kg}$ were required for both transplants. This was achieved in the younger patients in $97 \%$ and in the elder patients in $95 \%$.

The toxicity of IEV in the younger and elder patients (with dose reduced IEV) was similar (table 3). The majority of patients developed WHO grade 3/4 hematological toxicity. There was one WHO grade 3 infectious complication in an elder patient. The gastrointestinal toxicity WHO grade 3/4 was somewhat higher in elder patients with $18 \%$ versus $10 \%$ in the younger patients. An ifosfamide-related encephalopathy which required the application of methylene blue occurred in 1 of the younger $(3 \%)$ and in 1 of the elder $(5 \%)$ patients. There were singular cases of a WHO grade 3/4 nephrotoxicity among younger and elder patients. No treatment-related mortality was observed in both groups.

\section{Discussion}

Effective blood stem cell collections could be carried out after combination chemotherapy with ifosfamide, epirubicin and etoposide followed by G-CSF in patients with multiple myeloma. Both in younger and elder patients, similar collection results with a median of around $10 \times 10^{6} \mathrm{CD} 34^{+}$cells $/ \mathrm{kg}$ after a median of two leukaphereses were obtained. In the younger patients, the IEV regimen was applied in a $100 \%$ dosage. The younger patients had received more previous chemotherapy with a median of 4 cycles. In elder patients, the IEV dosage was generally reduced to $75 \%$ because of concerns regarding toxicity. Elder patients had received less previous chemotherapy with a median of 0 cycles due to a strategy of early stem cell harvesting. In patients with no conventional chemotherapy before stem cell harvesting, dexamethasone alone had been given for symptom control and stability of disease during the harvesting period. These results demonstrate that a strategy of early stem cell collection in elder patients with dose-reduced mobilizing chemotherapy can result in a similar high collection efficiency than in younger patients being treated according to the conventional strategy of stem cell mobilization after 3-4 cycles of induction chemotherapy.

The stem collections in our patients aimed at a minimum dose of $4 \times 10^{6} \mathrm{CD} 34^{+}$cells $/ \mathrm{kg}$ to support a tandem transplantation procedure. This target dose was achieved in $\geq 95 \%$ of both younger and elder patients. When compared to the collection results obtained after high-dose cyclophosphamide $\left(4-7 \mathrm{~g} / \mathrm{m}^{2}\right)$ with G-CSF in multiple myeloma, collection results appear to be superior with IEV [17, 18]. Indeed, in lymphoma patients, it was found that a mobilization with IEV and G-CSF gave superior collection results than high-dose cyclophosphamide with G-CSF [15]. In a study in lymphoma and multiple myeloma, high-dose ifosfamide alone with GM-CSF was compared with high-dose cyclophosphamide followed by GMCSF regarding stem cell collection results [19]. Blood stem cell collections yielded slightly less CD $34^{+}$cells after highdose ifosfamide but without statistical significance. The toxicity profile, however, after high-dose ifosfamide was favorable. This shows that ifosfamide can make an important contribution to stem cell mobilization within combination chemotherapy regimes.

In order to avoid the substantial hematological and non-hematological toxicity after high-dose cyclophosphamide, lower doses of cyclophosphamide $\left(1.5 \mathrm{~g} / \mathrm{m}^{2}\right)$ were investigated for stem cell mobilization in lymphoma and multiple myeloma [20]. A target dose of $2.5 \times 10^{6} \mathrm{CD}^{+} 4^{+}$ cells/kg to support a single transplant, however, could be harvested in only $64 \%$ of patients. This shows that reducing myelosuppression also reduces the following stem cell mobilization and collection during the post-nadir hematological rebound.

Blood stem cell mobilization with G-CSF alone at a higher dose of $10 \mu \mathrm{g} / \mathrm{kg}$ or above has the advantage of a low toxicity and the days of collection can be precisely planned. Yet, the collection results frequently are inferior to what can be obtained with the combination of chemotherapy and hematopoietic growth factors for mobilization $[21,22]$. This, however, does not necessarily lead to an inferior engraftment [22].

Several studies have shown that pretreatment with melphalan decreases stem cell mobilization and collection results significantly $[9,17]$. In our study, only 1 younger patient $(3 \%)$ and 1 elder patient $(5 \%)$ had received previous melphalan treatment.

In order to ameliorate toxicity, ifosfamide was given over several hours and a glucose infusion was co-administered. In around $10 \%$ of cases, neurotoxicity developed in our patients which presented as an encephalopathy and required a therapy with methylene blue in 1 younger $(3 \%)$ and 1 elder (5\%) patient. Severe WHO grade 3/4 nephrotoxicity occurred in $\leq 5 \%$ of cases. The majority of younger and elder patients receiving IEV with G-CSF developed a hematological toxicity WHO grade $3 / 4$. It therefore is required to perform regular blood tests and a clini- 
cal evaluation of the patient, for example three times weekly after discharge of the patient from the hospital following the administration of IEV chemotherapy. Platelet transfusions may be necessary in some patients. There is a potential risk of neutropenic fever around day 10 and a potential risk of bacterial sepsis has to be taken into consideration. Altogether, the toxicity profile appears to be adequate when put into relation with the high efficiency of this regimen in stem cell mobilization and collection.

\section{References}

1 Attal M, Harousseau JL, Stoppa AM, Sotto JJ, Fuzibet JG, Rosse JF, Casassus P, Maisonneuve $\mathrm{H}$, Facon $\mathrm{T}$, Ifrah $\mathrm{N}$, Payen $\mathrm{C}$, Bataille $\mathrm{R}$ : A prospective, randomized trial of autologous bone marrow transplantation and chemotherapy in multiple myeloma. N Engl J Med 1996;335:91-97.

2 Barlogie B, Jagannath S, Vesole DH, Naucke S, Cheson B, Mattox S, Bracy D, Salmon S, Jacobson J, Crowley J, Tricot G: Superiority of tandem autologous transplantation over standard therapy for previously untreated multiple myeloma. Blood 1997;89:789-793.

3 Lenhoff S, Hjorth M, Holmberg E, Turession I, Westin J, Nielsen JL, Wisloff F, Brinch L, Carlson K, Carlsson M, Dahl IM, Gimsing P, Hippe E, Johnson H, Lamvik J, Lofvenberg E, Nesthus I, Rodjer S: Impact on survival of high-dose therapy with autologous stem cell support in patients younger than 60 years with newly diagnosed multiple myeloma: A population-based study. Blood 2000;95:7-11.

4 Morgan GJ, Davies FE, Hawkins K, Brown J, Bell SE, Drayson MT, Selby PJ, Child A: The MRC myeloma VII trial of standard versus intensive treatment in patients $<65$ years of age with multiple myeloma. Blood 2002;100: $178 \mathrm{a}$.

5 Gianni AM, Siena S, Bregni M, Tarella C, Stern AC, Pileri A, Bonadonna G: Granulocyte-macrophage colony-stimulating factor to harvest circulating haemopoietic stem cells for autotransplantation. Lancet 1989;ii:580-584.

6 Gianni AM, Tarella C, Siena S, Bregni M, Boccadoro M, Lombardi F, Bengala C, Bonadonna G, Pileri A: Durable and complete hematopoietic reconstitution after autografting of rhGM-CSF exposed peripheral blood progenitor cells. Bone Marrow Transplant 1990;6: 143-145.

7 Demuynck H, Delforge M, Verhoef G, Zachée $\mathrm{P}$, Vandenberghe $\mathrm{P}$, Boogaerts M: Comparative study of peripheral blood progenitor cell collection in patients with multiple myeloma after single-dose cyclophosphamide combined with rhGM-CSF or rhG-CSF. Br J Haematol 1995;90:384-392.
8 Demirer T, Buckner CD, Gooley T, Appelbaum FR, Rowley S, Chauncey T, Lilleby K, Storb R, Bensinger WI: Factors influencing collection of peripheral blood stem cells in patients with multiple myeloma. Bone Marrow Transplant 1996;17:937-941.

9 Tricot G, Jagannath S, Vesole D, Nelson J, Tindle S, Miller L, Cheson B, Crowley J, Barlogie B: Peripheral blood stem cell transplants for multiple myeloma: Identification of favorable variables for rapid engraftment in 225 patients. Blood 1995;85:588-596.

10 Attal M, Harousseau JL, Facon TH, Guilhot F, Doyen C, Fuzibet JG, Monconduit M, Hullen C, Caillot D, Bouabdallah R, Voillat L, Sotto JJ, Grosbois B, Bataille R: Double autologous transplantation improves survival of multiple myeloma patients: Final analysis of a prospective randomized study of the 'Intergroupe Francophone du Myelome' (IFM 94). Blood 2002;100:5a.

11 Palumbo A, Triolo S, Argentino C, Bringhen S, Dominietto A, Rus C, Omede P, Tarella C, Pileri A, Boccadoro M: Dose-intensive melphalan with stem cell support (MEL100) is superior to standard treatment in elderly myeloma patients. Blood 1999;94:1248-1253.

12 Badros A, Barlogie B, Siegel E, Morris C, Desikan R, Zangari M, Fassas A, Anaissie E, Munshi N, Tricot G: Autologous stem cell transplantation in elderly multiple myeloma patients over the age 70 years. Br J Haematol 2001;114:600-607.

13 Siegel DS, Desikan KR, Mehta J, Singhal S, Fassas A, Munshi N, Anaissie E, Naucke S, Ayers D, Spoon D, Vesole D, Tricot G, Barlogie $\mathrm{B}$ : Age is not a prognostic variable with autotransplants for multiple myeloma. Blood 1999; 93:51-54.

14 Sirohi B, Powles R, Treleaven J, Mainwaring P, Kulkarni S, Pandha H, Bhagwati N, Horton C, Singhal S, Mehta J: The role of autologous transplantation in patients with multiple myeloma aged 65 years and over. Bone Marrow Transplant 2000;25:533-539.

15 McQuaker IG, Haynes AP, Stainer C, Anderson S, Russell NH: Stem cell mobilization in resistant or relapsed lymphoma: Superior yield of progenitor cells following a salvage regimen comprising ifosphamide, etoposide and epirubicin compared to intermediate-dose cyclophosphamide. Br J Haematol 1997;98:228233.
16 Sutherland DR, Anderson L, Keeney M, Nayar $\mathrm{R}$, Chin-Yee I: The ISHAGE guidelines for CD $34^{+}$cell determination by flow cytometry. $\mathrm{J}$ Hematother 1996;5:213-226.

17 Goldschmidt H, Hegenbart U, Wallmeier M, Hohaus S, Haas R: Factors influencing collection of peripheral blood progenitor cells following high-dose cyclophosphamide and granulocyte colony-stimulating factor in patients with multiple myeloma. Br J Haematol 1997;98: 736-744.

18 Fitoussi O, Perreau V, Boiron JM, Bouzigon E, Cony-Makhoul P, Pigneux A, Agape P, Nicolini F, Dazey B, Reiffers J, Salmi R, Marit G: A comparison of toxicity following two different doses of cyclosphosphamide for mobilization of peripheral blood progenitor cells in 116 multiple myeloma patients. Bone Marrow Transplant 2001;27:837-842.

19 Vela-Ojeda J, Tripp-Villanueva F, MontielCervantes L, Sanchez-Cortes E, Ayala-Sanchez M, Guevara-Moreno ME, Garcia-Leon LD, Rosas-Cabral A, García-Ruiz Esparza MA, Gonzalez-Llaven J: Prospective randomized clinical trial comparing high-dose ifosfamide + GM-CSF vs. high-dose cyclophosphamide + GM-CSF for blood progenitor cell mobilization. Bone Marrow Transplant 2000;25:11411146.

20 Bellido M, Sureda A, Martino R, Madoz P, Garcia J, Brunet S: Collection of peripheral blood progenitor cells for autografting with low-dose cyclophosphamide plus granulocyte colony-stimulating factor. Haematologica 1998;83:428-431.

21 Kröger N, Zeller W, Hassan HT, Krüger W, Renges H, Hummel K, Gutensohn K, Lölliger C, Zander AR: Successful mobilization of peripheral blood stem cells in heavily pretreated myeloma patients with G-CSF alone. Ann Hematol 1998;76:257-262.

22 Desikan KR, Barlogie B, Jagannath S, Vesole DH, Siegel D, Fassas A, Munshi N, Singhal S, Mehta J, Tindle S, Nelson J, Bracy D, Mattox $\mathrm{S}$, Tricot G: Comparable engraftment kinetics following peripheral-blood stem-cell infusion mobilized with granulocyte colony-stimulating factor with or without cyclosphosphamide in multiple myeloma. J Clin Oncol 1998;16: 1547-1553. 